\title{
Pensamento numérico e geométrico nos anos finais do ensino fundamental: Um
}

\section{estudo de caso}

\author{
Numerical and geometric thinking in the final years of elementary education: A case study \\ Pensamiento numérico y geométrico en los últimos años de educación primaria: Un estudio de caso
}

Recebido: 03/07/2021 | Revisado: 07/07/2021 | Aceito: 08/07/2021 | Publicado: 17/07/2021

\author{
Francisco Cleuton de Araújo \\ ORCID: https://orcid.org/0000-0002-5955-6324 \\ Secretaria Municipal de Educação de Fortaleza, Brasil \\ E-mail: cleutonaraujo86@gmail.com \\ Jonathan Haryson Araújo Aguiar \\ ORCID: https://orcid.org/0000-0001-5341-8935 \\ Secretaria Estadual de Educação do Ceará, Brasil \\ E-mail: jonathan.haryson@gmail.com
}

\begin{abstract}
Resumo
Este artigo retrata um estudo de caso realizado na Escola Professora Vicentina Campos, em Fortaleza (Ceará), incluindo duas turmas dos anos finais do Ensino Fundamental. Nossos objetivos foram: analisar a utilização de material didático (módulos de ensino) no apoio ao ensino de Matemática; comparar o desempenho de alunos submetidos ao ensino de Matemática com uso destes módulos de ensino como recurso didático, com o desempenho de estudantes submetidos apenas ao ensino tradicional. Utilizamos como fonte de coleta de dados os resultados de uma avaliação escrita e nossa observação participante. Os resultados demostraram que a utilização do material didático de apoio, em conjunto com uma metodologia que possibilita a construção de relações significativas, contribuíram com aspectos positivos relevantes ao ensino, além de proporcionar um melhor desempenho da turma que utilizou tais módulos. O presente artigo é fruto de um Trabalho de Conclusão de Curso (TCC) no âmbito da pós-graduação em Matemática, na Universidade Federal do Ceará (UFC).
\end{abstract}

Palavras-chave: Matemática; Ensino; Aprendizagem; Números; Geometria.

\begin{abstract}
This article portrays a case study carried out at Escola Professora Vicentina Campos, in Fortaleza (Ceará), including two classes from the final years of elementary school. Our objectives were: to analyze the use of didactic material (teaching modules) to support the teaching of Mathematics; to compare the performance of students submitted to Mathematics teaching using these teaching modules as a didactic resource, with the performance of students submitted only to traditional teaching. We use the results of a written assessment and our participant observation as a source of data collection. The results showed that the use of educational support material, together with a methodology that enables the construction of significant relationships, contributed with positive aspects relevant to teaching, in addition to providing a better performance of the class that used such modules. This article is the result of a Course Completion Paper (TCC) within the postgraduate course in Mathematics, at the Federal University of Ceará (UFC).
\end{abstract}

Keywords: Mathematics; Teaching; Learning; Numbers; Geometry.

\section{Resumen}

Este artículo presenta un caso de estudio realizado en la Escola Professora Vicentina Campos, en Fortaleza (Ceará), que incluye dos clases de los últimos años de la escuela primaria. Nuestros objetivos fueron: analizar el uso de material didáctico (módulos didácticos) para apoyar la enseñanza de las Matemáticas; comparar el desempeño de los estudiantes que cursan la enseñanza de Matemáticas utilizando estos módulos de enseñanza como recurso didáctico, con el desempeño de los estudiantes que cursan únicamente la enseñanza tradicional. Usamos los resultados de una evaluación escrita y nuestra observación participante como fuente de recopilación de datos. Los resultados mostraron que el uso de material de apoyo educativo, junto con una metodología que posibilita la construcción de relaciones significativas, contribuyó con aspectos positivos relevantes para la docencia, además de brindar un mejor desempeño de la clase que utilizó dichos módulos. Este artículo es el resultado de un Documento de Finalización de Curso (TCC) dentro del curso de posgrado en Matemáticas, en la Universidad Federal de Ceará (UFC).

Palabras clave: Matemáticas; Enseñando; Aprendiendo; Números; Geometría. 


\section{Introdução}

Frequentemente a Matemática ainda é encarada como uma espécie de vilã para grande parte dos estudantes. Assuntos deslocados da realidade do educando, exagero de abstrações e fórmulas prontas, assim como metodologias que tendem a não potencializar a atuação do aluno podem acabar contribuindo para que esta visão negativa continue se aprofundando na sociedade.

Refletindo sobre esta aversão generalizada e a lacuna que existe no desenvolvimento do pensamento numérico e geométrico, consideramos de fundamental importância discutir de forma mais profunda sobre tais problemáticas e procurar meios que possam transformar o ensino-aprendizagem de matemática de maneira positiva, mesmo que dentro de parâmetros que envolvem um estudo de caso.

Nesta investigação, almejamos observar os possíveis efeitos da aplicação, em sala de aula do Ensino Básico, de um conjunto que inclui material de apoio ao ensino de matemática e metodologias alternativas na prática docente. O material didático de apoio (módulos) que utilizamos em nossa pesquisa foi oferecido a partir de um curso de pós-graduação em Matemática, a nível de especialização, produto de uma parceria entre a Secretaria Municipal de Educação de Fortaleza (SME), o Departamento de Matemática da Universidade Federal do Ceará (UFC) e a Fundação Cearense de Apoio ao Desenvolvimento Científico e Tecnológico (FUNCAP).

O material didático que utilizamos nesta pesquisa abrange duas importantes áreas da Matemática: Números e Geometria. E no intuito de nortear e fundamentar nossa prática de ensino, analisamos o que a Base Nacional Comum Curricular (BNCC) e os Parâmetros Curriculares Nacionais (PCN's) dizem sobre estas duas áreas.

Para além disso, introduzimos nesta pesquisa temas que são amplamente discutidos na educação matemática atualmente. Nos propomos a refletir sobre a relevância da história da matemática como ferramenta auxiliar ao ensino, a contribuição da filosofia e como o currículo escolar pode ser analisado a partir de distintas abordagens teóricas.

Nosso comprometimento com a melhoria do ensino-aprendizagem de matemática nos leva a incentivar práticas didáticas que façam sentido para os estudantes, fazendo, sempre que possível, a ligação entre a sala de aula e o cotidiano de nosso aluno. Também consideramos que para que isso ocorra de verdade é essencial que o educador saiba articular conteúdos de ensino e os conhecimentos prévios dos estudantes. Isto é, saber estimular o indivíduo a construir criticamente o pensamento matemático, operando relações entre novos e antigos saberes.

É fundamental que o professor tenha a devida medida de interação com os alunos, que permita conhecer as dificuldades, os pontos fortes e fracos. Para daí atuar precisamente de acordo com nível de conhecimento que o aluno já possui e onde se pretende chegar, não subestimando o potencial do indivíduo.

Tendo em vista a superação de práticas tradicionais, agimos de maneira a propiciar um ambiente motivador, atraente e de intensa troca experiências e saberes, possibilitando, deste modo, a inserção de temas matemáticos e fundamentos lógicos de forma qualificada.

Isto posto, pontuando ainda a importância dos aspectos metodológicos que envolvem o ofício da docência, esta investigação tem como objetivos: 1) analisar a utilização de material didático de apoio no ensino de matemática; 2) comparar o desempenho de estudantes submetidos ao ensino de matemática com uso do material de apoio como recurso didático, com o desempenho de estudantes submetidos ao ensino de matemática baseado apenas nos materiais tradicionais.

O processo de pesquisa se deu em uma escola pública da rede municipal de Fortaleza - Ceará, envolvendo duas turmas do $9^{\circ}$ ano do Ensino Fundamental, perfazendo um total de 65 alunos. E como fonte de dados, recorremos a um teste escrito e a nossa observação participante em sala de aula no percurso das aplicações dos módulos.

No percurso de elaboração desse trabalho, apresentamos alguns dos resultados parciais da pesquisa que realizamos no V Congresso Nacional de Pesquisa e Ensino em Ciências (CONAPESC 2020). Esperamos que as reflexões aqui apresentadas 
possam contribuir com elementos que dinamizem o ensino-aprendizagem de Matemática.

\section{Ensino de Matemática à Luz da História da Matemática}

A Matemática é uma criação humana, assim como as demais ciências e as artes. Deste modo, na promoção de uma educação que almeja o desenvolvimento pleno do indivíduo, a convivência com a Matemática e seu percurso na história deve ser assegurada. A Matemática é parte importante do repertório cultural e científico da humanidade. Apropriar-se deste repertório cultural é, portanto, uma maneira do ser humano se realizar, potencializando suas capacidades como homem (Fossa, 2020).

Uma consequência lógica desta compreensão é que a escola terá um papel social e cultural significativo na potencialização desta apropriação. O professor deve estimular estratégias que favoreçam o desenvolvimento do pensamento matemático. O educando deve deter habilidades matemáticas elementares, sabendo interagir apropriadamente com essa importante herança cultural.

D’Ambrosio $(2009$, p. 7) ver a "matemática como uma estratégia desenvolvida pela espécie humana ao longo de sua história para explicar, para entender, para manejar e conviver com a realidade sensível, perceptível e com o seu imaginário, naturalmente dentro de um contexto natural e cultural".

Desta maneira, a Matemática pode ser encarada como parte do esforço da humanidade em aprimorar sua relação com a natureza e seu convívio em sociedade. Esta ciência é parte de um sistema racional altamente eficaz para se compreender e atuar na realidade concreta. E, ao longo do tempo, a educação tem sido um meio para a transmissão do saber matemático.

Contraditoriamente, essa herança cultural matemática tem sido continuamente negligenciada. Ao ponto de se tornar parte do senso comum dizer que o pensamento matemático é algo restrito a um pequeno número de indivíduos geniais. Este alheamento atua no sentido oposto ao pleno desenvolvimento do ser humano.

Apesar da nítida importância, a situação que o ensino de matemática enfrenta é bastante problemática. É perceptível o enorme desinteresse de crianças e jovens pelo conhecimento matemático. Indubitavelmente, um dos fatores que influenciam nessa falta de interesse é a maneira como se ensina matemática. Existe um hiato entre a herança matemática e o estudante, que necessita ser reparado.

Um problema de tal envergadura, com diversas variáveis, não admitirá uma solução trivial. Porém, é parte de nosso dever tentar esboçar uma contribuição no intuito de superar tais desafios.

Defendendo uma Matemática que se ligue a situações mais imediatas, como forma de reverter tais problemas, D’Ambrosio (2009, p. 32) revela que "o grande desafio é desenvolver um programa dinâmico, apresentando a ciência de hoje relacionadas a problemas de hoje e ao interesse dos alunos".

Descobrir quais os interesses dos educandos e saber articular os componentes curriculares com estes anseios é condição sine que non para reparar parte da problemática. Por exemplo, muitos alunos gostam de utilizar as redes sociais e, sabendo disso, o professor pode se utilizar de tais recursos como forma de aproximação e motivação. Assim, o amplo interesse pelas novas tecnologias não deve estar dissociado do conhecimento matemático.

Muitos estudantes revelam que a aversão à Matemática reside no fato de que os assuntos estudados são demasiadamente abstratos e não servirão para nada em suas vidas.

O aluno precisa enxergar certo sentido naquilo que lhe é apresentado. Ao invés de partir da aplicação de uma fórmula, por exemplo, o educador pode mostrar as razões pelas quais tal aparato teórico foi desenvolvido, o que ele pretende dar conta.

Alguns livros, de maneira acertada, já trazem uma situação motivadora na introdução a cada tópico a ser estudado. Inserir e relacionar os conteúdos matemáticos a contextos compreensíveis é uma forma importante de dar significado a determinados conceitos abstratos. 
Argumentando que a Matemática também tem uma essência abstrata e que o raciocínio lógico também é uma forma de pensamento abstrato, pontua-se a necessidade de aplicação prática dos conhecimentos matemáticos e a busca pela compreensão dos conteúdos desta disciplina através de relações com coisas que lhes concedam um sentido mais "concreto" (Roque, 2012).

Em medida oposta ao exagero de abstrações, pensamos que o educador precisa buscar, sempre que possível, relacionar conteúdos matemáticos à vida cotidiana do aluno. Ao aproximar conteúdos fundamentalmente abstratos da realidade do educando, espera-se obter um maior grau de interesse por conteúdos matemáticos.

Dar dinamismo aos assuntos trabalhados em sala de aula, no intuito de localizar tais conteúdos dentro de um contexto maior, que opera problemas atuais, é fundamental para se estabelecer um maior envolvimento dos estudantes no processo de construção da aprendizagem.

Mesmo em assuntos considerados mais abstratos, o educador precisa saber interligar conteúdos de ensino a um conjunto acessível de conexões lógicas que tenham significado para o estudante. Ou seja, conceder aos objetos estudados uma dimensão um pouco mais concreta.

Neste sentido, também entendemos que "uma percepção da história da matemática é essencial em qualquer discussão sobre a matemática e o seu ensino" (D’Ambrosio, 2009, p. 29).

A partir desta compreensão, julgamos que a história da matemática deve se fazer presente em nossas salas de aula de maneira habitual. O uso dessa poderosa ferramenta teórica pode inclusive reduzir a distância entre a abstração matemática e o cotidiano do educando.

Por sua vez, o educador também deve se munir desse arsenal histórico. Compreender o ensino e a matemática dentro de uma dimensão histórica dará ao sujeito uma melhor fundamentação para intervir na realidade escolar.

Desta maneira, pensamos que a história da matemática também contribui como elemento dinamizador na educação científica em geral e no ensino de matemática em particular. Estimular a compreensão dos fundamentos da ciência e do método científico é dever urgente em uma sociedade que simplesmente despreza o conhecimento científico.

Com isso, também queremos manifestar que não se trata de formarmos historiadores da matemática, o que se propõe, na verdade, é utilizar de forma apropriada tal ferramenta no sentido de promover melhoria na compreensão de conteúdos matemáticos, ampliando o horizonte cultural e mostrando, ao mesmo tempo, que a matemática não nasce pronta. Tratando-se de uma construção coletiva que envolve diversos grupos culturais ao longo dos séculos (Carvalho, 2019).

A sala de aula pode ser um espaço para construção do conhecimento matemático que vai muito além da aplicação de fórmulas prontas e acabadas, ampliar o repertório cultural e científico de nossos alunos deve estar no centro de nossas preocupações.

Esta investigação se insere dentro de um cenário que busca elementos que possam contribuir para que o aluno consiga, verdadeiramente, realizar toda sua potencialidade no campo da aprendizagem matemática.

Passemos, então, a um breve relato de tópicos da história dos números e da geometria. Vale ressaltar que não temos a pretensão de construir um estudo histórico que esgote tais temas. Na verdade, nosso uso da ferramenta histórica tem como objetivos: mostrar a matemática como construção humana; motivar o ensino-aprendizagem de matemática em nossas salas de aula; e mostrar alguns aspectos que ilustram os primórdios do pensamento numérico e raciocínio geométrico.

\subsection{Os números numa perspectiva histórica}

O conceito de número e o processo de contagem surgiram antes dos registros históricos que se tem, mas evidências arqueológicas apontam que o ser humano já era capaz de contar há 50 mil anos. Admite-se que o senso numérico estava presente no homem desde as épocas mais primitivas, sabiam reconhecer mais e menos em pequenas coleções de objetos. É 
provável que a forma mais antiga de se contar se ligue a algum tipo simples de correspondência biunívoca. Ranhuras em barro ou rocha, entalhes em madeira ou mesmo nós em cordas estão entre as primeiras formas que a humanidade encontrou para registrar contagens. Posteriormente surgiram expressões verbais para registrar o número de objetos. E, tempos depois, com o desenvolvimento da escrita, surgiram os primeiros símbolos para registrar números (Eves, 2011).

Ao tomarmos a história dos números através das evidências encontradas até hoje, no contexto do nascimento da escrita, os registros arqueológicos apontam para a Mesopotâmia, região onde atualmente se localiza o Iraque, há cerca de 6000 anos.

Para Roque (2012, p. 25), "o surgimento da escrita e da matemática nessa região estão intimamente relacionados. As primeiras formas de escrita decorreram da necessidade de registrar quantidades, não apenas de rebanhos, mas também de insumos relacionados à sobrevivência e, sobretudo, à organização da sociedade".

Ressalta-se, portanto, o aspecto prático da Matemática nesta origem, auxiliando no cotidiano a tomada das melhores decisões.

Os primeiros números inventados não representavam valores abstratos, mas marcas impressas que indicavam medidas de grãos. Posteriormente, os sinais que representavam quantidades começaram a ser acompanhados por ideogramas, que se relacionavam com os objetos contados. Isso foi um passo importante rumo à abstração, já que os registros de quantidades poderiam servir para objetos de diversas naturezas. Cabe ainda ressaltar que a vida econômica desses povos era ativa e tinham que lidar com inúmeros tipos de objetos (Roque, 2012).

Ao passo que a humanidade aprimora suas ferramentas de contagem, consolida-se o número como ente abstrato. Entendendo-se os aspectos históricos como um processo complexo, não linear e progressista.

Os sistemas de numeração variavam de acordo com cada situação, sendo possível utilizar sinais idênticos em relações numéricas distintas. Desta forma, os símbolos não representavam valores absolutos, variavam de acordo com o que se queria contar. Analisando a matemática mesopotâmica, pode-se afirmar que o sistema de numeração evolui de uma fase na qual se utilizava o contador impresso diversas vezes até um momento mais econômico, onde a impressão de tal contador diminui na sua forma e tamanho. Também já é possível observar a essência do sistema posicional, onde um mesmo símbolo pode representar distintos números, dependendo da posição em que ocupa (Roque, 2012).

Outra civilização em que há registros importantes desses primórdios é o antigo Egito. Por sorte, diversos papiros matemáticos se preservaram ao longo do tempo, servindo-se de fonte primária para diversos estudos e pesquisas. Mas, cabe observar que a matemática do antigo Egito nunca atingiu o mesmo patamar que a babilônica. Possivelmente devido ao fato do desenvolvimento econômico ser mais evoluído nessa segunda civilização.

No antigo Egito, a matemática começa a se desenvolver a partir de atividades administrativas. $\mathrm{O}$ ato de quantificar e registrar bens conduziu ao desenvolvimento de um sistema de medidas, que foi sendo empregado e aperfeiçoado por escribas. Os papiros de cunho matemático traziam situações pedagógicas, com problemas e soluções, com intuito de formar os mais jovens no enfrentamento de situações similares, provindas das atividades de administração de coletas e distribuição de insumos (Roque, 2012).

Desse período, podemos destacar documentos importantes como, por exemplo, o Papiro de Rhind ou de Ahmes, assim como os papiros Kahun, de Berlim e de Moscou.

De acordo com Roque (2012, p. 59),

O sistema decimal egípcio já estava desenvolvido por volta do ano 3000 a. E.C., ou seja, antes da unificação do Egito sob o regime dos faraós. O número 1 era representado por uma barra vertical, e os números consecutivos de 2 a 9 eram obtidos pela soma de um número correspondente de barras. Em seguida, os números eram múltiplos de 10, por essa razão, diz-se que tal sistema é decimal. O número 10 é uma alça; 100, uma espiral; 1 mil, a flor de lótus; 10 mil, 
um dedo; 100 mil, um sapo; e 1 milhão, um deus com as mãos levantadas.

Importante ressaltar que com esse sistema sofisticado os egípcios podiam representar praticamente quaisquer números, incluindo números muito grandes.

Com oitenta e cinco problemas matemáticos, o Papiro de Rhind pode ser considerado uma espécie de livro matemático da época. O texto inclui frações, multiplicações, divisões, a chamada regra da falsa posição, áreas, volumes, além de problemas de ordem prática.

Os papiros de Rhind e Moscou são considerados as principais fontes desse período. Este último possui vinte e cinco problemas, praticamente todos tratando de situações da vida prática.

Outro aspecto que iremos discorrer aqui é sobre o sistema de numeração maia. A civilização maia desenvolveu-se na América Central, há cerca de 3 mil anos, abrangendo regiões localizadas no México, Guatemala, Honduras, Belize e El Salvador. Tem contribuições sofisticadas em diversas áreas, tais como: matemática, arquitetura, engenharia, arte, astronomia, dentre outras.

O sistema de numeração maia é vigesimal, ou seja, tem base vinte. Outro aspecto curioso é que o zero, mais precisamente o símbolo equivalente a ele, era utilizado de forma consistente (Eves, 2011).

Em seu calendário, na representação entre intervalos de tempo, os maias utilizavam numeração posicional, com base principal vinte e base auxiliar cinco. Aos moldes do povo babilônico, correspondendo ao uso das bases sessenta e dez, respectivamente (Boyer, 1974).

Por sua vez, o sistema indo-arábico recebe esse nome por causa do povo hindu, que o inventou, e devido ao povo árabe que o multiplicou pela Europa Ocidental. Os registros mais remotos do uso desse conjunto de símbolos foram realizados em colunas de pedras na Índia, em torno de 250 a.C. Posteriormente, por volta de 800 d. C., foram introduzidos os conceitos de valor posicional e um zero, através do matemático persa Al-Khowârizmî, que descreve o sistema hindu em um livro de 825 d.C. (Eves, 2011).

Leonardo Fibonacci, com sua obra Liber Abaci de 1202 d.C., consolida a simbologia indo-arábica e o sistema posicional por toda a Europa.

\subsection{Apontamentos sobre a história da geometria}

Os babilônios relacionavam sua geometria com a mensuração. Conheciam regras gerais da área do retângulo, dos triângulos retângulos e isósceles e do trapézio. Assim como, o volume de um paralelepípedo reto-retângulo e de um prisma reto de base trapezoidal. Concebiam que o comprimento da circunferência era o triplo do diâmetro e sua área como um duodécimo da área de um quadrado de lado igual ao comprimento da circunferência considerada. Mas a principal característica da geometria babilônica é sua marca algébrica, utilizavam conceitos tidos como geométricos em problemas de álgebra. Tinham conhecimento de propriedades dos triângulos retângulos e do teorema de Pitágoras (Eves, 2011).

Por sua vez, diz-se que o desenvolvimento da geometria egípcia tem estreita relação com problemas de agrimensura, tendo em vista a produção de grãos às margens do rio Nilo. Os egípcios sabiam calcular áreas e volumes. Parte importante dos problemas contidos nos papiros de Rhind e Moscou podem ser considerados geométricos.

De acordo com Roque, "os mesopotâmicos e egípcios realizavam cálculos com medidas de comprimentos, áreas e volumes, e alguns de seus procedimentos aritméticos devem ter sido obtidos por métodos geométricos, envolvendo transformações de áreas. Isso não quer dizer, contudo, que possuíssem uma geometria” (Roque, 2012, p. 78).

Para além dos debates historiográficos, vamos nos deter mais precisamente, nesse breve texto, à geometria grega.

Tales é a primeira figura a qual se associam inúmeras descobertas da matemática. Em geometria, pode-se citar: que o 
diâmetro realiza uma bissecção do círculo; que os ângulos da base de um triângulo isósceles são congruentes; que os ângulos opostos pelo vértice são congruentes; que dois triângulos, com dois ângulos e um lado congruentes, são iguais; que um ângulo inscrito em uma semicircunferência é reto (resultado conhecido pelos babilônios 1400 anos antes). Vale ressaltar que tais resultados não foram obtidos pela intuição ou experimentação, a grandeza está no fato de que foram obtidos a partir de raciocínios lógicos (Eves, 2011).

Um diferencial da geometria grega é justamente a utilização do método dedutivo, com definições, demonstrações e encadeamento lógico.

Mas um fato relevante que devemos mencionar é que tanto Tales, como Pitágoras, são figuras imprecisas na história da matemática, haja vista que nenhuma de suas obras resistiram ao tempo. O pouco que sabe foi inferido a partir da obra de outros personagens históricos.

Apesar dos pouquíssimos registros, aponta-se que a escola pitagórica possuía uma incrível crença na matemática e na filosofia. Seus membros estudavam com afinco estas duas áreas do conhecimento. Ademais, dizem que o lema da ordem era "tudo é número". Evidenciando-se, desta forma, a profunda relação entre os pitagóricos e a matemática.

Tradicionalmente, atribui-se a Pitágoras de Samos o teorema envolvendo triângulos retângulos, onde o quadrado da hipotenusa é igual à soma dos quadrados dos catetos. Entretanto, mais de mil anos antes de Pitágoras, os babilônios já conheciam tal teorema. Pode ser Pitágoras o autor da primeira demonstração geral. Existem inúmeras conjecturas sobre a referida demonstração, mas ao que parece se deu por decomposição de figuras geométricas (Eves, 2011).

O Plimpton 322, tablete babilônico de 3700 anos, apresenta cerca de sessenta números que correspondem a "ternos pitagóricos". Ou seja, números que satisfazem o famoso "teorema de Pitágoras". Isso há cerca de mil anos antes do nascimento de Pitágoras. O tablete cuneiforme não se encontra em perfeitas condições de preservação, e também apresenta algumas poucas exceções numéricas, mesmo assim é possível afirmar, de forma robusta, que as "triplas pitagóricas" já eram de fato conhecidas nesse período.

Sabe-se, atualmente, que tal relação era conhecida por vários povos mais antigos que o povo grego e pode, inclusive, ter sido um conhecimento comum na época em que viveu Pitágoras (Roque, 2012).

Desta forma, o famoso teorema de "Pitágoras" não parece ter sido estudado pelos pitagóricos em sua forma geométrica, relacionando lados do triângulo retângulo. Ao que parece, a descoberta dos incomensuráveis também creditada aos pitagóricos deve ter uma origem distinta. Essa descoberta foi fundamental para a separação entre geometria e aritmética, a primeira comportando as grandezas geométricas e a segunda os números. Tal separação vem a ser uma marca distintiva na geometria grega, pelo menos como foi disseminado por Euclides (Roque, 2012).

Por sua vez, também não se sabe muito sobre a vida de Euclides de Alexandria. Pode ser que tenha sido discípulo da Academia de Platão de Atenas. E que, a convite de Alexandre, O Grande, tenha chefiado a famosa escola (e museu) de Alexandria. Por volta de 300 a. C., escreveu Os Elementos, uma obra monumental que por dois milênios foi o livro didático de matemática mais difundido e utilizado em todo o mundo.

Euclides não escreveu apenas os Elementos, que se tornou praticamente sinônimo de seu nome. Ele publicou por volta de uma dúzia de tratados, contemplando distintos assuntos, tais como: óptica, astronomia, música, mecânica e secções cônicas. As obras que resistiram ao tempo estão entre os tratados mais antigos da Grécia, porém mais da metade do escreveu se perdeu, incluindo nisto uma de suas obras mais relevantes que versava sobre cônicas. Dentre os tratados que se perderam, estão Lugares geométricos e Porismas (que poderia conter uma aproximação com o que denominamos hoje de geometria analítica). Apenas cinco tratados de Euclides conseguiram resistir ao tempo: Os Elementos, Os dados, Divisão de figuras, Os fenômenos e Óptica (Boyer, 1974).

De acordo com Aaboe (2013, p. 53), 
Os Elementos consistem em treze Livros, como são chamados, e a simples tradução do texto, sem comentários, formaria um grande volume impresso. Nestes treze livros, Euclides incorpora todo o conhecimento matemático acumulado em sua época, com algumas exceções notáveis, como as secções cônicas e a geometria esférica, e possivelmente algumas descobertas próprias. Seu grande feito é a apresentação do material sob uma bela forma sistemática e seu tratamento dele como um todo.

Portanto, os Elementos não é uma produção matemática exclusiva de Euclides, trata-se de uma espécie de livro texto que compila boa parte da elaboração matemática mais desenvolvida à época. Uma obra que resulta dos conhecimentos acumulados por distintos povos ao longo do tempo. Entretanto, destaca-se o tratamento rigoroso dado por Euclides à obra como elemento fundamental para sua vigência, sucesso e influência.

O livro abrange uma série de assuntos matemáticos, tais como: construções elementares, congruência, áreas, teorema de Pitágoras, álgebra geométrica, círculos, teoria dos números, proporções, polígonos regulares, figuras semelhantes, geometria no espaço, volumes, sólidos geométricos, dentre outros. Outro aspecto fundamental é o modo como foi sistematizado, reunindo definições, postulados e demonstrações.

As construções geométricas são feitas com régua e compasso. Uma explicação para isso seria a necessidade de se ordenar e sistematizar a geometria, com intuito de estabelecer uma melhor arquitetura da matemática. No período em que Euclides viveu, o conjunto de saberes produzidos por inúmeros geômetras já era muito desenvolvido, por isso havia uma necessidade de ordenar todo esse conhecimento. Tal ordem previa uma certa gradação, em nível crescente de complexidade. Euclides se propôs sistematizar o que havia de matemática elementar, que se utilizava exclusivamente da régua e compasso (Roque, 2012).

A matemática da Grécia Antiga atinge seu ápice no período helenístico. Sem dúvida, um dos problemas mais complexos para os historiadores especializados é reconstruir o que aconteceu antes de Euclides. Fora um pequeno trabalho de Autolico, tratando sobre astronomia, não restou nenhuma obra matemática completa desta época (Aaboe, 2013).

Em relação à divisão entre geometria e aritmética, no contexto da matemática grega, Saito nos fornece uma rica explicação.

Segundo Saito (2015, p. 38), “a geometria e a aritmética eram consideradas duas ciências distintas porque tinham dois objetos distintos de investigação".

Deste modo, "a aritmética era comumente definida como a ciência dos números" (Saito, 2015, p. 38). Enquanto "a geometria era a ciência das figuras e, geralmente designava o que hoje conhecemos como geometria plana" (Saito, 2015, p. 39).

Posteriormente, ambas as áreas, assim como muitas outras, foram aglutinadas dentro de uma única ciência matemática.

\section{Matemática: Algumas Reflexões Filosóficas}

Concordamos com a seguinte afirmação de D'Ambrosio (2012, p. 169): "História e filosofia da matemática não se separam e para entender a História da Matemática devemos refletir sobre a filosofia da matemática e a natureza do conhecimento matemático".

Pensando neste caráter indissociável, esboçaremos, neste breve tópico, alguns elementos que permeiam as discussões que envolvem o ensino de matemática e a filosofia a partir de uma perspectiva crítica.

Ao discorrer em torno da questão que envolve o fenômeno da vida e as estratégias de sobrevivência que permitiram a evolução das espécies, D’Ambrosio analisa que "na sua evolução, as espécies homo foram além da pulsão de sobrevivência, comum a todas as espécies vivas, e desenvolveram capacidades mentais sofisticadas que permitiram transcender a 
sobrevivência, procurando explicações para fatos e fenômenos naturais e, posteriormente, para fatos sociais e culturais (D’Ambrosio, 2016, p. 22).

Assim, ao transcender a denominada pulsão de sobrevivência, nossa espécie desenvolveu dia após dia estratégias cada vez mais refinadas que buscam compreender os fenômenos da natureza, da sociedade e da cultura.

As ciências se incluem nestes meios investigativos sistematizados. A matemática, em particular, fundamenta boa parte das pesquisas científicas.

Porém, precisa-se observar que em relação as bases sólidas

Os matemáticos, eles próprios, aparentemente nunca duvidaram disso. Como toda comunidade científica, a dos matemáticos assenta suas práticas em pressupostos universalmente aceitos, em geral não questionados até que eventuais problemas obriguem-na a revê-los e de algum modo corrigi-los. Até que uma crise se instale, pressupõe-se tacitamente que as bases do edifício matemático sejam sólidas. Abre- se, assim, mão da certeza e da segurança absolutas para que o trabalho cotidiano não seja prejudicado, pois uma excessiva preocupação com os fundamentos pode ter efeito nocivo sobre a prática matemática, ainda mais se não se chega, como de hábito, a uma conclusão consensual sobre a melhor fundamentação (Silva, 2007, p. 27)

Por sua vez, a filosofia não deve ser encarada como uma espécie de freio ao desenvolvimento científico. É o oposto disto. Crise na fundamentação abre um momento propício à reflexão filosófica.

Como forma de ponderar e avaliar criticamente as bases ditas fundamentais e todo desencadeamento que se origina de tais compreensões preliminares, o ser humano pode dispor do aparato filosófico.

Depreende-se, desta forma, a "filosofia como a reflexão ampla sobre ação: a razão de se estar agindo, a fundamentação dessa ação, os objetivos e consequências não imediatas da ação. Essa reflexão dos indivíduos é espontânea e intrínseca à vida, geralmente inconsciente e não explicitada. É fruto da evolução do indivíduo desde seu nascimento" (D’Ambrosio, 2016, p. 22).

Evidentemente, a matemática, assim como o seu ensino e a educação como um todo estarão em constante processo de crítica-reflexiva. Neste contexto, o comportamento questionador é muito bem-vindo, sendo parte importante da batalha pelo progresso científico e cultural.

Por muito tempo reservou-se o fazer matemático para os indivíduos geniais, que eram vistos como seres abençoados por entidade divina. Infelizmente, esse modo de enxergar a matemática (restrita a sujeitos praticamente infalíveis e brilhantes) acabou prevalecendo na sociedade (D’Ambrosio, 2012).

A nosso ver, esta forma de conduzir o processo de se ensinar matemática fortaleceu uma concepção elitista de educação. Desta forma, a situação crítica em que se encontra o ensino de matemática tem forte entrelaçamento com essa concepção tradicional.

Ademais, essa forma elitista de se fazer matemática colabora com a manutenção do status quo. Exclui a maior parcela dos indivíduos do pensamento matemático aprimorado.

Nota-se ainda que

Uma consequência disso é uma educação de reprodução, formando indivíduos subordinados, passivos e acríticos. A alternativa que proponho é orientar o currículo matemático para a criatividade, para a curiosidade e para crítica e questionamento permanentes, contribuindo para a formação de um cidadão na sua plenitude e não para ser um instrumento do interesse, da vontade e das necessidades das classes dominantes. A invenção matemática é acessível a todo indivíduo e a importância dessa invenção depende do contexto social, político, econômico e ideológico (D’Ambrosio, 2012, p. 165).

Com tudo isso não é de se admirar a apatia generalizada dos estudantes em relação à matemática. As formas 
tradicionais de ensino precisam ser criticadas e transformadas.

Percebe-se, ao longo do tempo, que essa maneira de se educar, privilegiando o simples ato de reproduzir procedimentos técnicos e anulando a reflexão crítica fracassou. Hoje, buscamos transformar a prática docente no sentido de fortalecer no aluno o espírito crítico, reflexivo e que aguça a curiosidade. A participação e envolvimento discente na construção do conhecimento matemático é fundamental. Defende-se que todo e qualquer indivíduo possa ter acesso ao pensamento matemático elaborado.

Fazer matemática é próprio a todo indivíduo humano. Mas não a matemática formal, inspirada no modelo de Euclides. Ao longo do tempo e em diversos locais, agrupamentos socializaram distintas maneiras de realizar observações, comparações, classificações, ordenações, quantificações, medições, explicações, generalizações e inferências no intuito de produzir e organizar conhecimento. Adquire-se e admite-se tais conhecimentos com certo grau de espontaneidade, pois os mesmos têm utilidade e servem a um fim. Entretanto, isso vai além da questão ligada à sobrevivência, extrapola-se na investigação de fatos e fenômenos que se organizam como mitos e espiritualidade. Estes conhecimentos possuem utilidade para todo o grupo (D’Ambrosio, 2016).

Portanto, variados grupos humanos desenvolveram suas formas de fazer matemática, inclusive transcendendo para a compreensão de fenômenos da natureza. Daí, cabe refletir por quais motivos se gerou um abismo entre a matemática escolar e os diversos sujeitos que passam por este ambiente.

Acreditamos que o excesso de formalismo e abstração contribuem para este abismo. Pois atuam no sentido contrário à criatividade. A padronização proposta pelo ensino tradicional afeta a curiosidade e o senso questionador do aluno.

Concordamos que

Como educadores matemáticos, cuidamos para que faça sentido nosso trabalho com os alunos. Certo, é preciso que saibamos (professores e alunos) o que estamos fazendo, portanto, que conheçamos as operações efetuadas, o discurso do texto matemático e sua linguagem proposicional e técnica, bem como respectivas aplicações. Mas, além disso, perseguimos o sentido que o conhecimento faz para nós, alunos e professores, pessoas presentes à situação de ensinar e de aprender, e para a região de inquérito da ciência, ou seja: que significado se revela na investigação do solo histórico (Bicudo, 2010, p. 27).

Portanto, em nosso fazer docente julgamos fundamental que o estudante consiga desenvolver aprendizagens que tenham sentido. Por este ângulo, vamos operar na mediação entre o conhecimento sistematizado e os saberes que os alunos trazem consigo.

A reflexão crítica deve estar presente em cada momento didático, tanto professores como estudantes precisam exercitar o ato de ponderação racional, atentando para razões mais profundas do ensino.

\section{Algumas Reflexões Críticas Sobre o Currículo}

Em educação, a temática currículo é permeada por intensos debates. A ideia aqui é esboçarmos alguns traços gerais e refletirmos sobre um assunto tão essencial ao fazer docente.

Vamos apresentar, primeiramente, uma acepção etimológica do termo currículo. De acordo com Sacristán (2013, p.

16),

Deriva da palavra latina curriculum (cuja raiz é a mesma de cursus e currere) [...]. Em sua origem, o currículo significava o território demarcado e regrado do conhecimento correspondente aos conteúdos que professores e centros de educação deveriam cobrir; ou seja, o plano de estudos proposto e imposto pela escola aos professores (para que o ensinassem) e aos estudantes (para que o aprendessem). De tudo aquilo que sabemos e que, em tese, pode ser ensinado ou aprendido, o currículo a ensinar é uma seleção organizada dos conteúdos a aprender, os quais, por sua 
vez, regularão a prática didática que se desenvolve durante a escolaridade.

Deste modo, cabe dar ênfase ao fato de que a instituição escolar impõe a docentes e discentes o currículo, que irá regular a prática em sala de aula.

Acrescentamos que tais planos de estudos refletem aspirações e concepções dominantes em cada sociedade, reproduzindo sobretudo valores políticos e econômicos.

Parte importante,

Da teorização curricular esteve centrada nos conteúdos como resumo do saber culto e elaborado sob a formalização das diferentes "disciplinas". Surge da tradição medieval que distribuía o saber acadêmico no trivium e no cuadrivium. E uma concepção que recolhe toda a tradição acadêmica em educação, que valoriza os saberes distribuídos em disciplinas especializadas - ou, quando muito, em áreas nas quais se justapõem componentes disciplinares - como expressão da cultura elaborada, transformando-as em instrumento para o progresso pela escala do sistema escolar, agora numa sociedade complexa que reclama uma maior preparação nos indivíduos. As modalidades e pujança desta concepção variam em diferentes momentos históricos (Sacristán, 2000, p. 39).

Portanto, na Idade Média, observa-se o que se pode caracterizar como uma primeira formalização de currículo. O trivium era constituído por gramática, retórica e dialética. Enquanto o cuadrivium era formado por aritmética, geometria, astronomia e música.

Sabe-se, no entanto, que esse conjunto de saberes era bastante restrito a uma ínfima parcela da sociedade. Desta forma, o acesso à cultura elaborada era bastante limitado e a escola não tinha como função social a inclusão.

Com efeito, em uma sociedade mais complexa, como a nossa, surgirão diversas concepções sobre currículo, cultura elaborada e saber sistematizado.

A partir de uma perspectiva crítica, encontramos em Freire uma rica contribuição ao debate sobre currículo, que se contrapõe à chamada educação bancária.

Assevera Freire (2005, p. 123),

Não reduzimos, por isso mesmo, sua compreensão, a do currículo explícito, a uma pura relação de conteúdos programáticos. Na verdade, a compreensão do currículo abarca a vida mesma da escola, o que nela se faz ou não se faz, as relações entre todos e todas as que fazem a escola. Abarca a força da ideologia e sua representação não só enquanto ideias, mas como prática concreta.

Depreende-se que a visão do autor sobre currículo é bastante ampla. E envolve uma batalha que não se limita ao campo das ideias, mas se reflete na prática educacional concreta. Existe um currículo explícito com os conteúdos formais, mas também existe um aspecto oculto que abrange as relações entre os diversos indivíduos que constituem a comunidade escolar.

De acordo com a perspectiva freiriana,

O currículo padrão, o currículo de transferência é uma forma mecânica e autoritária de pensar sobre como organizar um programa, que implica, acima de tudo, numa tremenda falta de confiança na criatividade dos estudantes e na capacidade dos professores! Porque, em última análise, quando certos centros de poder estabelecem o que deve ser feito em classe, sua maneira autoritária nega o exercício da criatividade entre professores e estudantes. O centro, acima de tudo, está comandando e manipulando, à distância, as atividades dos educadores e dos educandos (Freire \& Shor, 2008, p. 97).

Critica-se que o currículo padronizado tenha como característica a transmissão de conteúdos de maneira estática e autoritária. Inibindo com isso o potencial criativo de professores e estudantes. De longe da sala de aula, determinados centros de poder arquitetam o que educadores e educandos devem fazer. A partir do currículo padrão, tais centros de poder operam 
uma ingerência no ambiente escolar, manipulando-o de acordo com seus interesses.

Nega-se a autonomia dos protagonistas do processo educacional, reforçando assim uma educação do tipo bancária (não reflexiva, acrítica). Distanciando-se, portanto, de práticas emancipatórias. Ademais, essa imposição do chamado currículo oficial fortalece a fragmentação do conhecimento e atua em oposição à construção democrática dos saberes.

Deste modo, subverter tais amarras ideológicas de concepção tradicional, fortemente impregnadas de autoritarismo, estaria na ordem do dia. Professores e estudantes seriam responsáveis por forjar práticas libertadoras.

Existem indícios importantes que apontam que currículos, assim como as políticas educacionais de forma mais abrangente, sofrem influência de organismos internacionais e afetam de maneira negativa o trabalho no interior das instituições escolares e o trabalho pedagógico-didático dos educadores. Quando a educação escolar fica limitada e prioriza os critérios mercadológicos no equacionamento de problemas de cunho social ou econômico compromete-se o desenvolvimento da capacidade intelectual do estudante. Esse tipo de política empobrece o currículo e a didática, inibe o desenvolvimento do aluno e opera como fator de exclusão social (Libâneo, 2019).

Podemos intuir que os centros de poder acima citados correspondem, pelo menos em grande medida, à organismos político-financeiros aos moldes do Banco Mundial e Fundo Monetário Internacional.

Passemos agora à contribuição da chamada pedagogia histórico-crítica ao tema currículo.

Para Saviani (2011, p. 14),

A escola existe, pois, para propiciar a aquisição dos instrumentos que possibilitam o acesso ao saber elaborado (ciência), bem como o próprio acesso aos rudimentos desse saber. As atividades da escola básica devem organizarse a partir dessa questão. Se chamarmos isso de currículo, poderemos então afirmar que é a partir do saber sistematizado que se estrutura o currículo da escola elementar. Ora, o saber sistematizado, a cultura erudita, é uma cultura letrada. Daí que a primeira exigência para o acesso a esse tipo de saber seja aprender a ler e escrever. Além disso, é preciso conhecer também a linguagem dos números, a linguagem da natureza e a linguagem da sociedade.

Deste modo, conhecer as diversas linguagens é parte fundamental de qualquer currículo escolar. A escola deve oferecer aos alunos meios necessários para que possam acessar o conhecimento científico, assim como ofertar ao aluno o domínio de noções básicas das ciências. Nisso também se inclui o domínio da matemática elementar.

Existem elementos que são considerados clássicos dentro do currículo escolar, como matemática, ciências naturais, história e geografia. Inclusive ninguém contesta. Aliás, contesta-se a forma, mas não a importância de cada um desses elementos no currículo. Contudo, tais elementos clássicos são postos em segundo plano. Afirmam que tudo que a escola fizer, independentemente da importância, com validade ou não, será currículo. Isso é de fato um equívoco e pode ser melhor distinguido pelas terminologias curricular e extracurricular. Reserva-se, portanto, a terminologia currículo para as atividades fundamentais, das quais a escola não pode ficar sem desenvolver, com pena de perder sua especificidade. As outras atividades podem ser definidas como extracurriculares. Desta forma, as atividades extracurriculares devem atuar no sentido de fortalecer as atividades curriculares, e nunca deverão substituir ou prejudicar estas (Saviani, 2011).

Neste sentido, temas paralelos (comumente classificados como transversais) que surgem no contexto escolar devem estar a serviço do fortalecimento do saber sistematizado.

A escola tem como característica específica desenvolver a habilidade de apreensão do repertório cultural clássico da humanidade. E a Matemática deve ser vista a partir deste ângulo. Todo aluno deve ter o direito de acessar e dominar as ferramentas básicas deste incrível repertório cultural.

Por sua vez, a educação não pode ser refém de modismos, que "aparecem como algo muito avançado, mas, na verdade, apenas elidem questões até certo ponto óbvias, que não podiam ser perdidas de vista e que dizem respeito ao trabalho escolar" (Saviani, 2011, p. 86). 
Grosso modo, ninguém é contrário, por exemplo, que todo estudante domine as ferramentas básicas da aritmética, da álgebra e da geometria. Porém, muitas vezes se incorre no erro de diluir tais temas a tal ponto que acabam se situando em um segundo plano. Invertendo aspectos que são fundamentais da escola.

$\mathrm{Na}$ concepção de currículo que defendemos, a Matemática tem papel de destaque, juntamente com outros elementos clássicos da cultura. Não podemos perder a centralidade desse papel específico da escola, com risco de "contemporizar e prolongar as desigualdades vigentes" (Saviani, 2011, p. 86).

Por seu turno, o campo da educação matemática tem uma contribuição fundamental à discussão acerca do currículo. Vejamos agora alguns apontamentos desta área.

O currículo pode ser definido como uma estratégia para a ação de educar. É composto, de maneira integrada, por objetivos, conteúdos e métodos. E o objetivo não é a pessoa ter capacidade de repetir coisas que não se ligam à realidade de hoje. Neste contexto, uma reflexão que também se coloca necessária é que testes padronizados são uma maneira ainda mais inútil e enganadora de se avaliar do que exames e testes comuns (D’Ambrosio, 2009).

Devemos olhar o currículo de Matemática de forma integrada, conteúdos, objetivos e métodos devem estar em sintonia. Por exemplo, não adianta propor metodologias modernas, inclusive com alta tecnologia, se os objetivos e conteúdos estão presos ao passado (ao tradicional).

Cabe aqui uma crítica contundente aos chamados testes padronizados. Acreditamos que a avaliação deve ser realizada de forma abrangente, no intuito de gerar impacto positivo no ensino-aprendizagem. Avaliar não deve ser uma forma de punição ou exclusão.

De maneira alternativa, e com intuito de contribuir com a formação cidadã plena do indivíduo, propõe-se guiar o currículo escolar matemático no sentido de fomentar a criatividade, a crítica e o questionamento. Com a pretensão clara de escapar ao cerco imposto por vontades e necessidades da classe dominante. A matemática é acessível a todo e qualquer sujeito e a relevância desse campo se insere no contexto social, político, econômico e ideológico (D’Ambrosio, 1999).

Neste sentido, faz-se necessário se contrapor à subordinação e passividade. A justiça social deve se fazer presente em nossas preocupações sobre currículo. $\mathrm{O}$ ensino tradicional opera como uma âncora que faz naufragar o sujeito social. Livrar-se desse peso incômodo é parte essencial do fazer matemático.

De forma muito sucinta, apresentamos algumas reflexões em torno do currículo escolar. Percebe-se que o tema é trabalhado por vários estudiosos e correntes educacionais ao longo do tempo. Pensamos que o ensino de matemática não deve se furtar de tais discussões e pode, inclusive, continuar oferecendo elementos instigantes ao debate.

O tema currículo encontra-se no centro das discussões que envolvem educação. Compreender aspectos gerais dessa temática é fundamental para atuarmos de forma efetiva no fazer docente.

\section{Pensamento Numérico e Geométrico}

A Geometria e os Números têm papel de destaque na Base Nacional Comum Curricular (BNCC), constituindo duas das cinco unidades temáticas abordadas. O material didático de apoio utilizado nesta pesquisa envolve estas duas áreas.

No que diz respeito ao Ensino Fundamental, o documento evidencia que a unidade Números tem por objetivo atuar no desenvolvimento do pensar numérico, acarretando no conhecimento de variadas formas de exprimir quantidades, aprimorando com isso o julgamento e interpretação de afirmações que levam em consideração a quantidade (BRASIL, 2018).

Desta maneira, pode-se inferir que nossa expectativa é que o aluno desenvolva habilidades que estão além do simples "efetuar contas". É essencial que o discente consiga compreender as informações de forma correta e aprenda a relacionar tais situações ao universo dos números.

Pensar numericamente, de maneira consolidada, envolve sobretudo um amadurecimento intelectual que deve começar 
desde a primeira infância. Tal habilidade deve ser forjada no enfrentamento de situações-problema, em um contexto que tenha significado para o aluno.

Saber contar e exprimir quantidades em forma numérica devem estar em sintonia com a interpretação crítica dos dados. Raciocinar logicamente, contrariando muitas vezes o senso comum, precisa ser um exercício constante nas aulas de matemática.

Deste modo, torna-se deveras importante apresentar atividades que tenham significado para o aluno e ampliar progressivamente o estudo dos conjuntos numéricos. E nesses estudos, o professor deve dar ênfase ao registrar, operar, utilizar e dar significado (BRASIL, 2018).

Não é um trabalho fácil transpor conteúdos curriculares, que muitas vezes se apresentam de forma hermética, para o universo de nosso aluno. Faz-se necessário, portanto, que o professor compreenda mais amplamente situações que fogem aos conteúdos em si. A partir de uma visão analítica da realidade social e cultural, o professor, dialeticamente, irá aprimorar modos de transpor didaticamente temas matemáticos ao ensino. Logicamente, tal tarefa envolve tempo e comprometimento. Assim, a carga de planejamento precisa estar em consonância com a tarefa crítica reflexiva que se impõe ao docente.

Nesta mesma unidade temática, a BNCC pondera que o aprimoramento do raciocínio numérico vai para além desta unidade. A ampliação e aprofundamento deste pensamento se relaciona com a interligação com as outras áreas de conhecimento matemático: álgebra, geometria, grandezas e medidas e probabilidade e estatística (BRASIL, 2018).

Ao trabalharmos o pensamento numérico de forma ampla e satisfatória é comum estendermos o estudo dos Números à outras unidades temáticas. E isso também irá contribuir para a ampliação de uma visão mais panorâmica da ciência matemática.

Muitas vezes o professor irá trabalhar o pensar numérico partindo de problemas que requerem do aluno saberes que estão fora de tal unidade. Se, por um lado, isso vai exigir do estudante um pouco mais de habilidade, por outro, a consolidação da teoria tende a ser mais sólida. O indivíduo será levado a enxergar para além do trivial, amplificando sua capacidade de interrelacionar distintas áreas.

A nossa ver, uma forma interessante de se fazer isso, por exemplo, seria trabalhar números muito grandes no contexto das distâncias astronômicas, ou mesmo na informática. Números decimais nas transações comerciais e números negativos no futebol. São infinitas as possibilidades. Levando sempre em consideração as diversas maneiras de resolver um problema, não exigindo apenas um determinado tipo de solução. Abrindo espaço para criatividade e autonomia. Mas sem abrir mão do rigor inerente ao conhecimento científico.

Em diversos momentos do percurso de ensino, os alunos questionam diretamente sobre a necessidade de se estudar determinados conteúdos. Haja vista que os mesmos não iriam aparecer em sua vida prática. Acreditamos que uma das formas de mitigarmos tal situação é nos ampararmos em tópicos da história da matemática. Mas não uma história que privilegia uma visão tradicional de evolução alicerçada em indivíduos geniais, e sim uma histórica crítica que contextualiza social, cultural e filosoficamente o conhecimento matemático.

Em alternativa ao enfadonho estudo baseado na aplicação de fórmulas, repetição e memorização de conceitos puramente abstratos, os professores podem dinamizar sua prática didática trabalhando distintas estratégias de resolução de problemas. Buscando, deste jeito, superar o mero ato da reprodução de conteúdos e acumulação acrítica de informações. Agindo na consolidação do conhecimento científico como criação da humanidade, que se aprimorou ao longo do tempo.

O cálculo exato com números não deve anular as outras formas de realizar cálculos. Operar mentalmente, realizar aproximações e estimativas, assim como fazer uso de calculadoras são formas válidas. Tudo irá depender da adequação ao contexto.

No que diz respeito à unidade temática Geometria, a BNCC sinaliza que para desenvolver do pensamento geométrico 
é fundamental para que o discente consiga elaborar argumentos sólidos, sendo capaz de realizar deduções lógicas (BRASIL, 2018).

A argumentação lógico-dedutiva deve se amparar em propriedades geométricas estudadas anteriormente. É fundamental que o estudante consiga estabelecer correlações entre as diversas ideias e conceitos geométricos e sua realidade concreta.

O exagero na aplicação de fórmulas nas aulas de matemática acaba limitando a autonomia do educando e compromete o desenvolvimento de relações que tenha significado. Comprometendo, sobremaneira, a construção de conhecimentos. Podendo causar apatia, alheamento e pouco interesse.

Acreditamos que essa ênfase excessiva na memorização e aplicação de fórmulas reforça uma educação do tipo instrumental, onde o aluno é levado a no máximo operar em repetição conceitos abstratos. O estudante pode resolver uma equação porque simplesmente aprendeu a repetir aquele conjunto de procedimentos, mas não é capaz de refletir criticamente e estabelecer deduções, utilizando esse aparato matemático, em sua realidade social.

O momento de tensão e reflexão que surge a partir de uma situação-problema pode ser um forte aliado na compreensão mais profunda de conteúdos matemáticos. Muito além da instrumentalização e reprodução, o sujeito está imerso em um ambiente desafiador, onde a criatividade e a autonomia são valorizadas e encorajadas.

Não subestimar a capacidade cognitiva do educando e propiciar um ambiente motivador são tarefas contínuas do fazer docente. Essa construção de saberes precisa ser coletiva, os estudantes devem ser ganhos cotidianamente para essa tarefa.

Fazer esta ponte entre a bagagem de saberes que os discentes trazem e os conhecimentos a serem aprendidos é condição essencial na contraposição às práticas tradicionais de ensino, que se revelaram historicamente ineficazes e pouco contribuíram para a superação da reprodução acrítica de conteúdos.

Até bem pouco tempo, percebíamos, na educação básica, que a geometria era posta em segundo plano. Os livrostextos e o currículo escolar davam ênfase à aritmética e álgebra. E esse comportamento se refletia nas salas de aula. Felizmente, presenciamos uma transformação desta situação.

Por conseguinte, devemos resgatar na sociedade a importância de o indivíduo se apropriar dos fundamentos elementares da geometria e se habilitar na capacidade de fazer relações múltiplas entre tais fundamentos e a vida cotidiana.

Entendemos que a divisão temática tem caráter didático. Mas compreendemos que transcender a fragmentação de conteúdos dentro da matemática é um caminho natural a ser perseguido. O saber estritamente compartimentado tende a prejudicar uma compreensão mais ampla e rica.

Sempre que possível e respeitando as especificidades da ciência matemática, também é importante proporcionar interligações com outras áreas do conhecimento humano, no intuito de mitigar a fragmentação entre as distintas disciplinas.

O raciocínio geométrico, assim como o pensamento numérico, é um importante legado cultural da humanidade. E a instituição escolar deve oferecer os meios necessários para que os estudantes possam efetivamente acessar tais elaborações e operar suas ferramentas básicas de maneira corriqueira.

Até o momento a escola tem falhado nisso. Apontar o professor como principal responsável, ou mesmo o estudante, é a ação costumeira. Não compactuamos com tal disparate. As razões deste fracasso se relacionam centralmente à superestrutura sistêmica de nossa sociedade.

Nosso comprometimento com a melhoria do ensino de matemática nos faz ver que a problemática não se encerra em si mesma, o lugar historicamente destinado à educação como um todo, dentro da sociedade, deve ser constantemente questionado. A transformação que tanto almejamos terá a crítica como ferramenta essencial. 


\section{Aspectos Metodológicos}

Nossa pesquisa é do tipo empírica, com abordagem qualitativa. Trata-se também de um estudo de caso. A investigação que ora apresentamos foi realizada na Escola Professora Vicentina Campos, da rede municipal de Fortaleza Ceará, envolvendo duas turmas do $9^{\circ}$ ano do Ensino Fundamental, perfazendo um total de 65 alunos e, como fonte de dados, utilizamos uma avaliação escrita e nossa observação participante nas aulas de Matemática. E, em cada turma, aplicamos metodologias distintas.

Os objetivos em que trabalhamos foram: 1) analisar a utilização de material didático (módulos de ensino) no apoio ao ensino de Matemática; 2) comparar o desempenho de estudantes submetidos ao ensino de Matemática com uso do material de apoio como recurso didático, com o desempenho de estudantes submetidos ao ensino de Matemática baseado apenas nos materiais tradicionais.

Nas práticas de ensino na turma que denominamos "A", foi utilizado o material didático de apoio (módulos) e nos movemos em torno de metodologias que estimulavam a construção de relações significativas. A turma "B" teve apenas aulas expositivas no formato tradicional.

Como forma de avaliar as distintas práticas realizadas em ambas as turmas, utilizamos o parâmetro de desempenho na avaliação escrita e nossa observação participante das aulas.

Mesmo entendendo os limites de cada um destes recursos avaliativos, acreditamos que tais ferramentas podem extrair elementos relevantes no modo de se observar e comparar grupos distintos.

A opção por uma prova escrita se sustenta no fato de que estes instrumentos de avaliação são muito relevantes no processo de investigação do desempenho do estudante (Hoffmann, 2008).

Reiterando que uma avaliação padronizada não reflete toda a diversidade presente, nem encerra a dinâmica maior que abarca o processo educativo.

Cabendo ainda ponderar que analisar as notas em si não garante sucesso, pois depende de como foi formulada a avaliação (Moretto, 2002).

Deste modo, tivemos um minucioso cuidado na confecção da prova em questão, assegurando uma relação com os conteúdos estudados, com os objetivos planejados e as habilidades esperadas.

Ponderando novamente que os resultados de desempenho obtidos em um teste escrito podem não refletir a realidade de maneira adequada e com intuito de ampliar os instrumentos avaliativos, também vamos analisar os dados de nossa observação participante em cada uma das aplicações. Tais observações, cabe mencionar, foram feitas logo após cada aplicação em forma de relatórios escritos pelo educador.

Nesta perspectiva, nos somamos à ideia de que as melhores formas de avaliação são as tarefas e registros realizados pelo docente que fundamentam o resgate da memória significativa de todo o processo, possibilitando uma análise ampla do desenvolvimento de cada estudante (Hoffmann, 2010).

\subsection{Descrição dos materiais utilizados}

Os materiais de apoio (módulos de ensino) que utilizamos nesta pesquisa nos foram ofertados a partir de um curso de pós-graduação em matemática, em nível de especialização, ofertado pela Secretaria Municipal de Educação de Fortaleza (SME), em parceria com o Departamento de Matemática da Universidade Federal do Ceará (UFC) e a Fundação Cearense de Apoio ao Desenvolvimento Científico e Tecnológico (FUNCAP).

Os módulos de ensino utilizados configuram um material rico e atualizado que pode auxiliar o educador no processo de aprendizagem de conteúdos matemáticos. Tal material didático possui uma característica geral de priorizar o raciocínio lógico-quantitativo no desenvolvimento de habilidades em resolver situações-problemas. 
Os módulos que utilizamos em sala de aula tratam de Números e Geometria, correspondendo ao currículo do Ensino Fundamental.

Podemos exibir uma série de características comuns presentes nestes módulos, tais como: introdução, exemplos, figuras, conteúdo complementar, listas de exercícios e desafios e a solução das listas.

Verifica-se também uma preocupação em contextualizar historicamente cada um dos assuntos apresentados. Em diversos momentos, o material didático apresenta valiosas notas históricas. Por sua vez, as figuras (desenhos, fotos e toda parte gráfica) enriquecem muito cada módulo e contribuem com a compreensão dos conteúdos propostos. Os exemplos e exercícios exploram variados níveis de aprendizagem, do mais básico ao médio-avançado. Vale destacar também as inúmeras questões de avaliações de larga escala e de olímpiadas que integram o material. Na parte complementar, há indicações de livros, sites, vídeos, aplicativos e recursos manipulativos.

Dentro de nosso recorte de pesquisa, os módulos denominados "Interagindo com os Números" trabalham os números inteiros, a divisibilidade, os números racionais, as dízimas periódicas e os números irracionais. Por outro lado, os que tratam de Geometria trabalham o raciocínio geométrico, dois grandes problemas da geometria grega antiga (o túnel de Samos e a distância da Terra até a Lua), figuras planas e seus respectivos perímetros e áreas.

Por último, queremos ressaltar que a forma escrita apresentada (linguagem utilizada) nos módulos é bastante acessível, direta e concisa, possibilitando uma leitura enriquecedora e agradável. Este não é um elemento secundário, pois uma linguagem excessivamente técnica dificultaria a compreensão leitora.

\subsection{Descrição das aplicações}

A ideia é relatar, de forma sintética, algumas práticas que realizamos na turma em que aplicamos os módulos de ensino. Um elemento comum a todas as aulas foi a utilização de questões de matemática olímpica, especialmente da OBMEP, e também de provas externas (Prova Brasil, ENEM e SPAECE). Trabalhamos com diversas situações-problema, buscando sempre fomentar um ambiente desafiador, que fizesse sentido ao aluno. Uma de nossas metas era contribuir para o desenvolvimento do raciocínio lógico e do espírito de investigação, tendo como ponto de partida desafios matemáticos.

$\mathrm{Na}$ aula sobre raciocínio geométrico, demos ênfase à construção geométrica com régua e compasso. Também utilizamos, em menor medida, transferidor e esquadro. Discutimos aspectos históricos que envolvem o desenvolvimento da geometria e possíveis relações com os avanços tecnológicos contemporâneos. Assistimos a um pequeno vídeo, relacionando matemática com o universo lúdico.

$\mathrm{Na}$ abordagem sobre números inteiros e suas operações, revimos alguns sistemas de numeração, trabalhamos as operações a partir do uso da reta numérica e resolvemos diversos exemplos com a proposta lúdica de "bolas positivas" e "bolas negativas". Relembramos as propriedades da adição, da multiplicação e construímos uma tabuada compacta. Realizamos uma dinâmica envolvendo números inteiros com material de baixo custo. E estudamos o algoritmo da divisão.

A aula que abordou dois problemas da Grécia Antiga, apresentou uma contextualização histórica e refletiu sobre a questão do túnel de Samos e do cálculo da distância entre a Terra e a Lua. Mostramos um pequeno vídeo que ilustrava tais questões. Apresentamos também alguns axiomas e conceitos elementares da geometria euclidiana. E trabalhamos com régua e compasso.

No estudo sobre divisibilidade, partimos de elementos históricos, com destaque à figura de Gauss. Realizamos o chamado jogo das doze moedas. Trabalhamos números múltiplos, divisores, primos, compostos e o crivo de Erastóstenes. Vimos também o teorema fundamental da aritmética, fatoração, MDC e MMC.

Quando apresentamos o módulo sobre figuras planas, realizamos uma introdução ao tema a partir do reconhecimento da presença de figuras geométricas planas em nosso cotidiano. Trabalhamos a relação entre a geometria e a arte, tomando 
como ponto de partida uma atividade de colorir com obras de grandes artistas (Kandinsky, Modrian e Volpi). Estudamos características e propriedades das figuras planas. E realizamos uma dinâmica sobre as principais propriedades de algumas destas figuras (triângulo, quadrado, retângulo, trapézio e círculo).

De forma introdutória, na aula envolvendo números racionais, trabalhamos o conto "Os trinta e cinco camelos", do livro O Homem que Calculava de Malba Tahan. Estudamos as noções básicas de frações. Fizemos uma revisão das operações com frações (adição, subtração, multiplicação e divisão). Realizamos uma atividade em duplas abordando as distintas representações dos números racionais (fracionário, na língua materna, na forma geométrica e na forma decimal).

Como introdução ao estudo de perímetros de figuras planas, apresentamos a lenda de Dido e discutimos o desafio do buraco na folha de caderno que fosse suficientemente grande para que o corpo passasse dentro. Realizamos uma atividade lúdica em duplas relacionando malha quadriculada e perímetro, que consistia na construção das figuras planas, na medição dos comprimentos, no cálculo do perímetro, no nome e classificação de cada figura. No intuito de ressaltar o aspecto lúdico, pedimos à turma para colorir cada um dos polígonos.

$\mathrm{Na}$ abordagem de dízimas periódicas e números irracionais, apresentamos e calculamos vários exemplos. Trabalhamos com fração geratriz. Discutimos sobre o teorema de Pitágoras e a apreciação geométrica de medidas dadas por números irracionais, seja como diagonal de um quadrado seja como medida na reta.

No módulo sobre áreas de figuras planas, trouxemos à tona a discussão que envolve terminologias matemáticas e fizemos uma contextualização histórica sobre o cálculo de áreas no antigo Egito. Definimos área e, a partir disso, trabalhamos diversas áreas (quadrado, retângulo, triângulo, círculos e polígonos regulares em geral). Também realizamos uma atividade em duplas envolvendo área e malha quadriculada, os estudantes apresentaram e dialogaram com os demais colegas a solução dos problemas.

Por fim, aplicamos uma atividade individual, em forma de teste, que consistia numa prova com questões de avaliações externas. E corrigimos coletivamente as questões do teste, discutindo dúvidas e soluções alternativas.

Devido à pandemia do novo coronavírus, os demais módulos de ensino foram tratados à parte e não se inserem em nosso recorte de pesquisa. Mesmo assim, consideramos que tanto as aplicações realizadas como as avaliações contínuas do processo de ensino-aprendizagem respaldam nossa investigação. Obviamente, isso não esgota um debate tão rico e complexo. Entendemos que a pesquisa ora apresentada oferece elementos importantes para superação do ensino tradicional e aponta que recursos e metodologias são aspectos fundamentais na discussão sobre melhoria na educação matemática, especialmente na aprendizagem de conteúdos matemáticos.

Em sala de aula, atuamos com afinco no sentido de tornar o educando sujeito ativo do processo de ensinoaprendizagem. E mediando a interação entre os temas estudados e os conhecimentos prévios dos estudantes, no intuito de contribuir com o desenvolvimento de aprendizagens que tenham sentido para o aluno.

\section{Analisando os Dados}

A pesquisa que desenvolvemos tem um nítido objetivo se servir de apoio à melhoria do ensino de matemática. Em uma discussão tão complexa e problemática, não existe solução trivial. Precisa-se estabelecer hipóteses e parâmetros objetivos. Mesmo assim não acreditamos que tais premissas determinem a priori os resultados. A realidade frequentemente se mostra mais rica que nossos esquemas mentais.

Ao discutirmos os resultados desta investigação, precisamos deixar claro que a inserção de um recurso material em sala de aula por si só não irá refletir a imensa problemática pela qual atravessa o ensino de matemática. Nos propomos utilizar o material de apoio didático em nossas aulas de forma vinculada a uma proposta metodológica que investe na produção de relações significativas, considerando os conhecimentos que os alunos já possuem. 
Também não encaramos que, no âmbito dessa investigação, consigamos abarcar elementos que estão além da sala de aula, como fatores econômicos, políticos e sociais que, obviamente, vão influenciar fortemente na instituição escolar, no fazer docente e na produção de conhecimentos.

Contudo, enxergamos a relevância das reflexões aqui expostas como uma reação às dificuldades que enfrentamos no dia a dia do magistério. Não consideramos suficiente formar repetidores de informações, que não desenvolvem suas potencialidades de forma integral. Investimos na possibilidade de superação das práticas tradicionais de ensino, empenhandose fortemente na construção crítica do pensamento matemático. E por isso nos envolvemos na discussão de práticas educativas emancipatórias.

Com intuito de verificarmos as possíveis influências na aplicação dos módulos de ensino, em conjunto com metodologias alternativas, recorremos a verificação estatística de nossa hipótese, mas também analisamos aspectos subjetivos que escapam a mensuração numérica. Como instrumento de coleta de dados, utilizamos uma prova escrita e a observação participante nas aulas.

$\mathrm{Na}$ avaliação escrita havia dez questões do tipo objetiva, abrangendo conteúdos relacionados a números e geometria. Priorizamos itens de provas externas e olimpíadas de matemática, que se relacionam com os assuntos estudados e o currículo escolar do Ensino Fundamental. O tempo destinado à realização do teste foi o mesmo.

Ao analisarmos a comparação de desempenho na prova escrita entre os dois grupos, observamos que o grupo, denominado turma $\mathrm{A}$, que utilizou o material didático de apoio (módulos) obteve melhor resultado que a turma $\mathrm{B}$, que não utilizou tais módulos. A média da turma A foi 8,2, enquanto a turma B obteve 6,9 como média.

Pensamos que esse é um primeiro indício da efetiva contribuição na aprendizagem da utilização destes módulos de ensino em sala de aula, mas não de forma avulsa e sim de forma associada a uma metodologia que busca o desenvolvimento de relações significativas.

Para além desse forte dado inicial, trazemos agora um outro elemento importante para nossa análise. Ao analisarmos o rendimento das turmas com desempenho igual ou superior a $70 \%$ de acertos no teste escrito, observamos a tendência favorável da turma que denominamos A. Alunos com rendimento igual ou superior a $70 \%$ na turma A equivalem $81 \%$ da turma, enquanto que na turma B esta medida representou 65\%. Desta maneira, podemos inferir que houve relevante ganho na aprendizagem dos conteúdos matemáticos propostos.

Para além da nota na avaliação escrita, acompanhamos os dois grupos na realização das atividades em sala de aula, registrando em relatórios o desenvolvimento das práticas dos estudantes em um período de cinco meses.

$\mathrm{Na}$ turma A, o uso dos módulos didáticos de apoio, aliado a uma metodologia que favorece o desenvolvimento de aprendizagens significativas, provocou reações importantes no processo de ensino-aprendizagem. Os educandos mostraram-se mais motivados, interessados e empenhados.

\subsection{Relatório das aplicações}

Em cada uma das aplicações, foram realizados relatórios. Tais relatórios versavam sobre os seguintes tópicos: objetivo, material utilizado, conteúdos abordados, desenvolvimento, retorno dos alunos, apoio da gestão, sugestão de melhoria do módulo e resultado obtido.

Em relação aos objetivos, procuramos desenvolver competências e habilidades específicas à área em estudo, trabalhamos com o seguinte: rever operações com números inteiros; resolver situações-problema com números inteiros e suas operações; desenvolver o raciocínio lógico e o espírito de investigação, tendo como ponto de partida desafios matemáticos; estudar as dízimas periódicas; efetuar cálculos com números irracionais; resolver problemas envolvendo operações com números racionais; reconhecer diferentes representações de um mesmo número racional; resolver problemas utilizando adição 
ou subtração com números racionais representados na forma fracionária; estabelecer relações entre representações fracionárias e decimais dos números racionais; resolver problemas que envolvam as ideias de múltiplo e de divisor; investigar e estabelecer os critérios de divisibilidade de alguns números; classificar os números naturais em primos e compostos; calcular o MDC e o MMC; e resolver situações-problema que envolvam divisibilidade.

No campo da geometria, trabalhamos com as seguintes situações: rever conceitos da geometria plana; trabalhar desenho geométrico, com uso de régua e compasso; calcular perímetros de figuras planas; resolver problemas que envolvam o cálculo do perímetro de polígonos, usando malha quadriculada ou não; reconhecer figuras geométricas planas em nosso cotidiano; identificar formas geométricas em obras de grandes artistas plásticos; identificar características dos triângulos; classificar quadriláteros e identificar seus elementos; identificar círculo/circunferência e seus elementos; e reconhecer propriedades dos polígonos regulares.

Já em relação ao material utilizado, podemos citar: o módulo da especialização (UFC/SME); a BNCC; o banco de questões da OBMEP; lousa; pincel; compasso; régua; transferidor; esquadro; papel A4; lápis de cor; pequenos vídeos; e atividades impressas.

Quanto ao retorno dos alunos, na turma em que utilizamos os módulos de ensino, juntamente com a metodologia diferenciada, podemos dizer que a recepção foi positiva, que os estudantes se envolveram com os conteúdos estudados, que todos os alunos participaram das atividades propostas, e que vários estudantes pediram para ir à lousa demonstrar as soluções dos problemas propostos.

Ao discutirmos o apoio da gestão escolar, consideramos que o núcleo gestor mostrou-se parceiro e abraçou a ideia de aplicação dos módulos do curso de especialização.

Tendo em vista os módulos aplicados nas aulas, sugerimos como melhoria a ampliação das listas de exercícios, com foco nos anos finais do ensino fundamental. Haja vista que o formato inicial contemplava apenas o ensino médio.

Quanto aos resultados obtidos na turma A, a partir de nossa observação participante, notamos que a turma se mobilizou ativamente na resolução de problemas, acreditamos também que os conceitos foram bem assimilados e que os módulos contribuíram com o ensino de conceitos elementares de forma significativa. Ademais, a interação entre os pares mostrou-se bastante positiva, assim como as dinâmicas foram bem aceitas e produziram bons resultados.

Não evidenciamos tais resultados positivos na turma B, pouco interesse pelos conteúdos propostos e apatia dominaram o cenário.

\section{Conclusão}

Considerando como fundamental a contribuição da história da matemática ao contexto escolar e refletindo sobre o percurso histórico que envolve os primórdios do pensamento numérico e do raciocínio geométrico, nos empenhamos em mostrar a matemática como uma construção realizada por diversos povos ao longo do tempo. Não como algo que já nasce pronto e acabado. Também nos posicionamos frontalmente contra o obscurantismo e negação da ciência, que obstaculizam a construção coletiva do saber.

Ademais, também consideramos que a prática de ensino precisa se envolver com problemas da sua época. Esse caráter dinâmico da ciência em resolver problemas candentes pode motivar o aluno e gerar maior interesse. Fazendo a necessária interação entre o conhecimento matemático e o cotidiano do educando.

Tanto a instituição escolar como o professor devem estar abertos às concepções prévias que os estudantes trazem, reconhecendo a riqueza de experiências e vivências adquiridas fora do ambiente escolar. Partindo dessas concepções baseadas no senso comum e valorizando todo o potencial cognitivo do aluno, pretende-se realizar uma ressignificação de saberes.

Buscamos refletir sobre alguns aspectos que envolvem o debate sobre currículo escolar, resgatando as primeiras 
tentativas de sistematização e as posições de algumas correntes teóricas e pensadores da educação frente ao tema.

A padronização curricular, a partir da ingerência de organismos externos ao ambiente escolar, pode, de forma autoritária, inibir o potencial criativo de estudantes e professores. Ajudando a perpetuar um modelo de ensino baseado na transmissão de conteúdos, descolados do interesse social dos verdadeiros agentes do processo educativo.

Partindo de uma concepção histórico-crítica, defendemos que a instituição escolar deve assegurar aos estudantes os instrumentos cognitivos essenciais para que possam ter acesso ao conhecimento científico. E também habilitar o aluno na compreensão e domínio dos fundamentos básicos das ciências, incluindo aí a matemática elementar.

Em nossa investigação, trabalhamos com os objetivos de analisar o uso de material didático de apoio (módulos de ensino) nas aulas de matemática; e comparar o desempenho entre dois grupos de estudantes, distinguindo-se pelo uso ou não de tal material didático em cada turma.

A turma A, que fez uso dos módulos didáticos, demonstrou melhor rendimento na prova escrita. E para além deste aspecto quantitativo, essa turma desenvolveu outros fatores importantes, como motivação, empenho e interesse.

Portanto, concluímos que a inclusão do material didático de apoio (módulos de ensino), articulado a uma metodologia que estimule no estudante o processo de construção de conhecimentos, favorecendo também aprendizagens significativas, contribuiu com um melhor desempenho da turma A.

Em uma perspectiva futura de trabalho, queremos ampliar este estudo para um número mais amplo de estudantes. Também pretendemos analisar aspectos da temática pesquisada com alunos do ensino médio.

\section{Referências}

Aaboe, A. (2013). Episódios da história antiga da matemática. SBM.

Araujo, F. C. (2020). Estudo de áreas e perímetros nos anos finais do Ensino Fundamental sob o ângulo da História da Matemática. In: Anais do $V$ CONAPESC, v. 1. 1-5. Realize Editora

Araujo, F. C. (2020). Matemática nos anos finais do Ensino Fundamental: um estudo de caso. In: Anais do V CONAPESC, 1. 1-12. Campina Grande: Realize Editora.

Araujo, F. C. (2020). Vídeos no ensino de física: um estudo de caso. In: Castro, Paula Almeida de. (Org.). Avaliação: Processos e Políticas. Campina Grande: Realize Editora.

Bicudo, M. A. V. (2010). Filosofia da Educação Matemática segundo uma perspectiva fenomenológica. In: Bicudo, M. A. V. (Org.). Filosofia da Educação Matemática: fenomenologia, concepções, possibilidades didático-pedagógicas. 1, 23-47. Editora UNESP.

Boyer, C. B. (1974). História da Matemática. Editora Edgar Blucher.

Brasil. (1998). Parâmetros curriculares nacionais - matemática. MEC/SEF.

Brasil. (2018). Base Nacional Comum Curricular-BNCC. Educação é a Base. MEC.

Carvalho, J. B. P. (2019). História da Matemática no Ensino. Cadernos do IME - Série Matemática. 13, 99-106.

D’Ambrosio, U. (1999). História da Matemática: questões historiográficas e políticas e reflexos na Educação Matemática. In: Bicudo, M. A. V. (Org.). Pesquisa em Educação Matemática: concepções e perspectivas. Editora UNESP. 97-115.

D’Ambrosio, U. (2009). Educação matemática: da teoria à prática. (17a ed.) Papirus.

D’Ambrosio, U. (2016). Filosofia, Educação e Matemática em uma relação íntima. REVEMAT. 11, 21-35.

D’Ambrosio, U. (2012). Priorizar História e Filosofia da Matemática na Educação. Tópicos Educacionais. 18(1-2), 159-175.

Estrela, C. (2018). Metodologia Científica: Ciência, Ensino, Pesquisa. Editora Artes Médicas.

Eves, H. (2011). Introdução à História da Matemática. (5a ed.) Editora Unicamp.

Fossa, J. A. (2020). Lectura de textos históricos en el aula. Revista Paradigma, XLI. 116 - 132.

Freire, P. (2005). A educação na cidade. (6a ed.) Cortez.

Freire, P \& Shor, I. (2008). Medo e Ousadia: o cotidiano do professor. Paz e Terra. 
Research, Society and Development, v. 10, n. 8, e56010817838, 2021

(CC BY 4.0) | ISSN 2525-3409 | DOI: http://dx.doi.org/10.33448/rsd-v10i8.17838

Gil, A. C. (2002). Como elaborar projetos de pesquisa. (4 ed.) Atlas.

Hoffmann, J. (2008). Avaliar: respeitar primeiro, educar depois. Mediação.

Hoffmann, J. (2010). Avaliar para promover: as setas do caminho. Mediação.

Koche, J. C. (2011). Fundamentos de metodologia cientifica. Vozes.

Libâneo, J. C. (1998). Adeus professor, adeus professora? Novas exigências educacionais e profissão docente. Cortez.

Libâneo, J. C. (2019). Finalidades educativas escolares em disputa, currículo e didática. In: Libâneo, J. C.; Echalar A. D. L. F.; Suanno, M. V. R. \& Rosa, S. V. L. (orgs.). Em defesa do direito à educação escolar: didática, currículo e políticas educacionais em debate. VII Edipe. Goiânia: Editora da UFG.

Moretto, V. P. (2000). Construtivismo: a produção do conhecimento em sala de aula. DP \& A.

Moretto, V. P. (2002). Prova: um momento privilegiado de estudo não um acerto de contas. DP\&A.

Roque, T. (2012). História da Matemática: uma visão crítica, desfazendo mitos e lendas. Jorge Zahar.

Sacristán, J. G. (2000). O currículo: uma reflexão sobre a prática. (3 ed.) Artmed.

Sacristán, J. G. (2013). Saberes e incertezas sobre o currículo. Penso.

Saito, F. (2015). História da matemática e suas (re)construções contextuais. Editora Livraria da Física.

Saviani, D. (2011). Pedagogia histórico-crítica: primeiras aproximações. (11 ed.) Autores Associados.

Silva, J. J. (2007). Filosofias da Matemática. Editora UNESP. 